Article

\title{
Synthesis, Structural Characterization, and Antitumor Activity of a Ca(II) Coordination Polymer Based on 1,6-Naphthalenedisulfonate and 4,4'-Bipyridyl
}

\author{
Xishi Tai $^{1} *$ and Wenhua Zhao ${ }^{2}$ \\ 1 College of Chemistry and Chemical Engineering, Weifang University, Weifang 261061, China \\ 2 Department of Chemistry, Qinghai Normal University, Xining 810008, Qinghai Province, China; \\ E-Mail: zhaowenhua0214@163.com \\ * Author to whom correspondence should be addressed; E-Mail: taixs@1zu.edu.cn; \\ Tel.: +86-536-8785363; Fax: +86-536-8785363.
}

Received: 27 June 2013; in revised form: 12 July 2013 / Accepted: 7 August 2013 /

Published: 16 August 2013

\begin{abstract}
A novel $\mathrm{Ca}(\mathrm{II})$ coordination polymer, $\left[\mathrm{CaL}\left(4,4^{\prime} \text {-bipyridyl }\right)\left(\mathrm{H}_{2} \mathrm{O}\right)_{4}\right]_{n}$ ( $\mathrm{L}=1,6$-naphthalenedisulfonate), was synthesized by reaction of calcium perchlorate with 1,6-naphthalenedisulfonic acid disodium salt and 4,4'-bipyridyl in $\mathrm{CH}_{3} \mathrm{CH}_{2} \mathrm{OH} / \mathrm{H}_{2} \mathrm{O}$. It was characterized by elemental analysis, IR, molar conductivity and thermogravimetric analysis. X-ray crystallography reveals that the $\mathrm{Ca}$ (II) coordination polymer belongs to the orthorhombic system, with space group $P 2_{1} 2_{1} 2_{1}$. The geometry of the $\mathrm{Ca}$ (II) ion is a distorted $\mathrm{CaNO}_{6}$ pengonal bipyramid, arising from its coordination by four water molecules, one nitrogen atom of 4,4'-bipyridyl molecule, and two oxygen atoms from two L ligands. The complex molecules form a helical chain by self-assembly. The antitumor activity of 1,6-naphthalenedisulfonic acid disodium salt and the $\mathrm{Ca}$ (II) coordination polymer against human hepatoma smmc-7721 cell line and human lung adenocarcinoma A549 cell line reveals that the $\mathrm{Ca}$ (II) coordination polymer inhibits cell growth of human lung adenocarcinoma $A 549$ cell line with IC50 value of $27 \mu \mathrm{g} / \mathrm{mL}$, and is more resistive to human lung adenocarcinoma $A 549$ cell line as compared to 1,6-naphthalenedisulfonic acid disodium salt.
\end{abstract}

Keywords: $\mathrm{Ca}(\mathrm{II})$ coordination polymer; synthesis; structural characterization; antitumor activity 


\section{Introduction}

The last few decades, many studies have focused on the metal-organic hybrid materials constructed by $d$-block or $f$-block cations and organic ligands, because they have potential applications in catalysis [1], photoluminescence [2], gas storage [3], molecule-based magnetic materials [4] and biomedical materials [5]. In comparison to $d$-block cations, the coordination behavior and potential applications of alkaline earth metal complexes has remained largely an unexpored area [6]. As part of our group to explore the synthesis and properties of alkaline earth metal complexes, we have been exploring the preparation of metal-organic hybrid materials by combining alkaline earth metal ions and organic ligands containing multi-oxygen and nitrogen atoms [7-11]. In this paper, a new hybrid material, $\left[\mathrm{CaL}\left(4,4^{\prime}\right.\right.$-bipyridyl $\left.)\left(\mathrm{H}_{2} \mathrm{O}\right)_{4}\right](\mathrm{L}=1,6$-naphthalenedisulfonate) was synthesized and characterized by elemental analysis, IR, thermogravimetric analysis and X-ray structure analysis. On the basis that metal-organic frameworks can be used as delivery vehicles for drug molecules [12], the antitumor activity of 1,6-naphthalenedisulfonic acid disodium salt and its $\mathrm{Ca}$ (II) coordination polymer against human hepatoma smmc-7721 cell line and human lung adenocarcinoma A549 cell line also have been investigated.

\section{Results and Discussion}

\subsection{Molar Conductivity}

The molar conductance value of the $\mathrm{Ca}(\mathrm{II})$ coordination polymer in methanol solution $\left(1 \times 10^{-3} \mathrm{~mol} \mathrm{~L}{ }^{-1}\right)$ is $8.9 \mathrm{~S} \cdot \mathrm{cm}^{2} \cdot \mathrm{mol}^{-1}$, indicating that the $\mathrm{Ca}$ (II) coordination polymer is a nonelectrolyte [13].

\subsection{IR Spectra}

The IR spectrum of the $\mathrm{Ca}$ (II) coordination polymer exhibits ligand bands with the appropriate shifts due to complex formation. The $v\left(\mathrm{SO}_{3}{ }^{-}\right)$vibrations at $1336 \mathrm{~cm}^{-1}$ and $1201 \mathrm{~cm}^{-1}$ in the free 1,6-naphthalenedisulfonate ligand shift to lower frequencies and are observed at $1301 \mathrm{~cm}^{-1}$ and $1186 \mathrm{~cm}^{-1}$ for the complex, indicating that the oxygen atoms of $\mathrm{SO}_{3}{ }^{-}$coordinate to $\mathrm{Ca}$ (II) ions [14]. The IR spectrum of the $\mathrm{Ca}(\mathrm{II})$ coordination polymer displays peaks at $1219 \mathrm{~cm}^{-1}, 800 \mathrm{~cm}^{-1}$ and $607 \mathrm{~cm}^{-1}$ which may be attributed to the $v(\mathrm{C}=\mathrm{N})$ stretching of 4,4'-bipyridyl, showing that the nitrogen atoms of 4,4'-bipyridyl also take part in the coordination with calcium atom. In addition, at lower frequency the complex exhibits bands around $519 \mathrm{~cm}^{-1}$ and $417 \mathrm{~cm}^{-1}$ which may be assigned to $v(\mathrm{Ca}-\mathrm{N})$ and $v(\mathrm{Ca}-\mathrm{O})$ vibration.

\subsection{Structure Description}

A single-crystal X-ray crystallographic study reveals that the $\mathrm{Ca}(\mathrm{II})$ coordination polymer crystallizes in the space group $P 2{ }_{1} 2_{1} 2_{1}$ with $Z$ value of 4 . The basic unit consists of one $\mathrm{Ca}$ (II) center with distorted pengonal bipyramidal geometry (Figure 1). The coordination environment around $\mathrm{Ca}$ (II) is afforded by two oxygen atoms (O1 and $\mathrm{O} 4)$ from two 1,6-naphthalenedisulfonate ligands, four oxygen atoms $(\mathrm{O} 1 \mathrm{~W}, \mathrm{O} 2 \mathrm{~W}, \mathrm{O} 3 \mathrm{~W}$ and $\mathrm{O} 4 \mathrm{~W})$ from four coordinated water molecules, and one nitrogen 
atom (N1) from 4,4'-bipyridyl ligand. The $\mathrm{Ca}(\mathrm{II})$ coordination polymer molecules from one-dimensional chained helical structures by the $\pi-\pi$ interaction of the bridging ligand, 1,6-naphthalenedisulfonate (Figure 2). The helical chains are further connected by hydrogen bonds to form a three dimensional network structure (Figure 3). It is interesting that the 4,4'-bipyridyl only acts as monodentate ligand in the complex molecule. The distances of the $\mathrm{Ca}-\mathrm{O}$ bonds are in the range of $2.2982(13) \sim 2.4896(14) \AA$, and that of $\mathrm{Ca}-\mathrm{N}$ bond is $2.5934(15) \AA$, which are similar to the Ca-O bond lengths reported previously $[15,16]$. In addition, the formation of network benefits from the intermolecular and intramolecular hydrogen bonds (Table 1).

Figure 1. Coordination environment around the $\mathrm{Ca}(\mathrm{II})$ center in the coordination polymer.

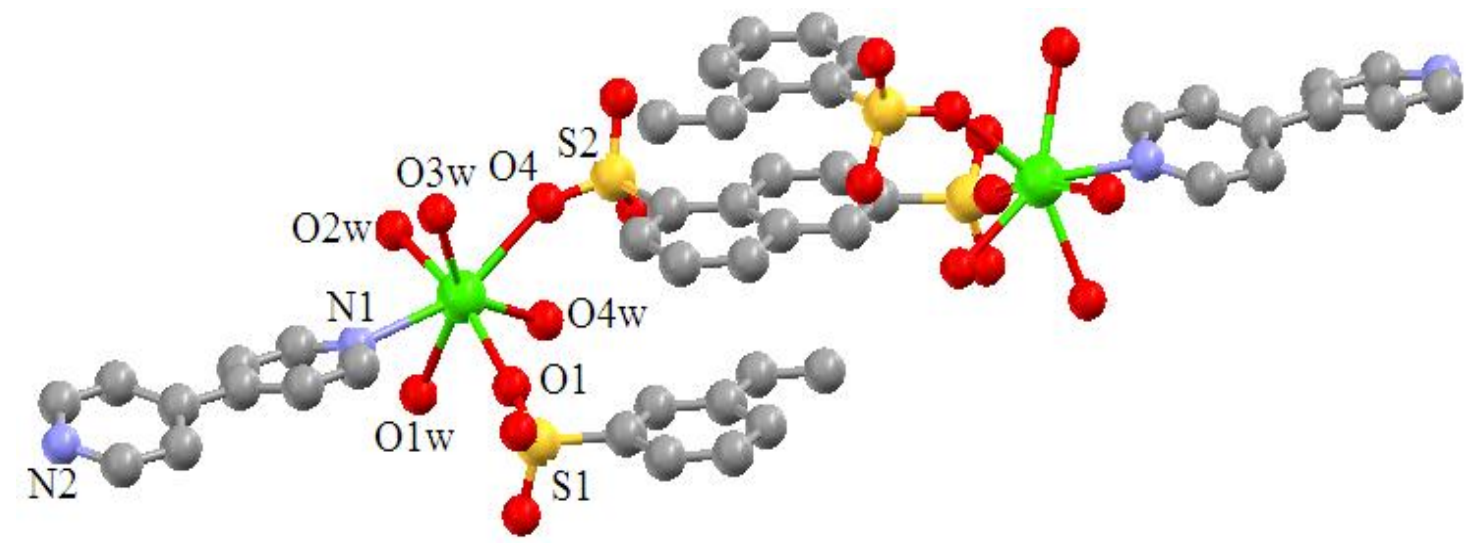

Figure 2. 1D chained helical structure of the $\mathrm{Ca}(\mathrm{II})$ coordination polymer. The uncoordinated $\mathrm{O}$ atoms and the $\mathrm{O}$ atoms from coordinated water molecules were omitted for clarity.

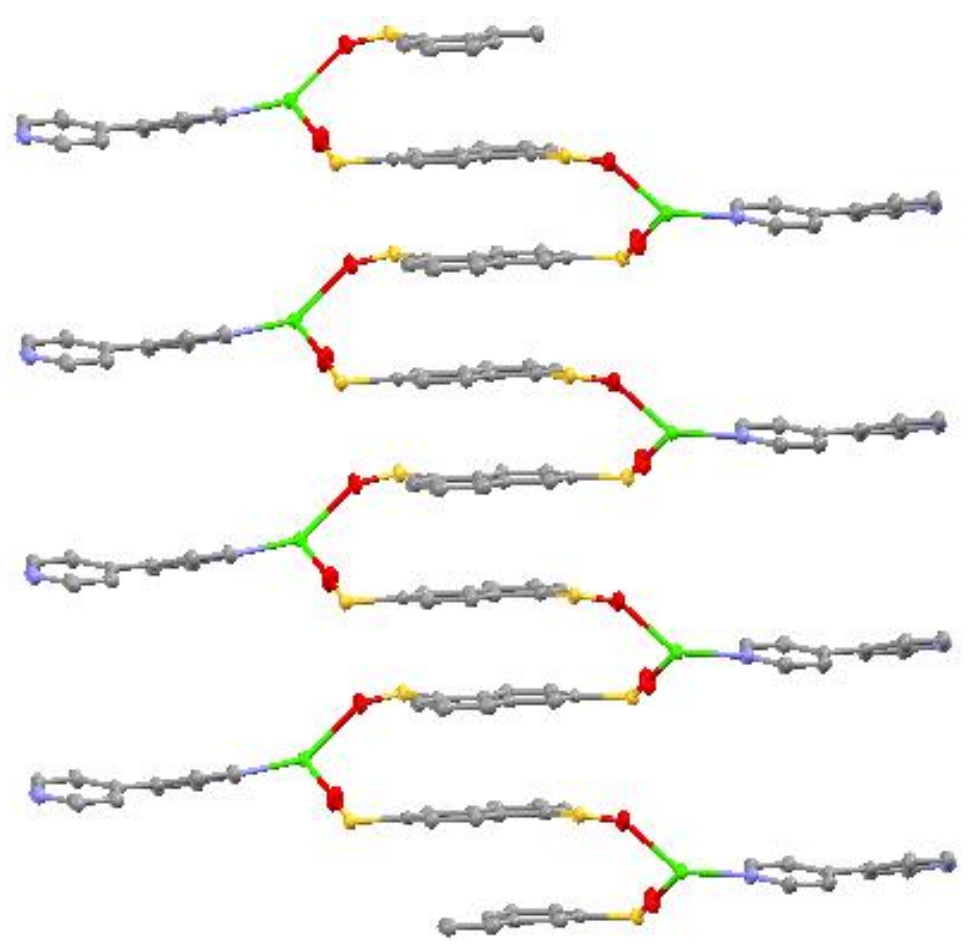


Figure 3. 3D network structure of the $\mathrm{Ca}(\mathrm{II})$ coordination polymer.

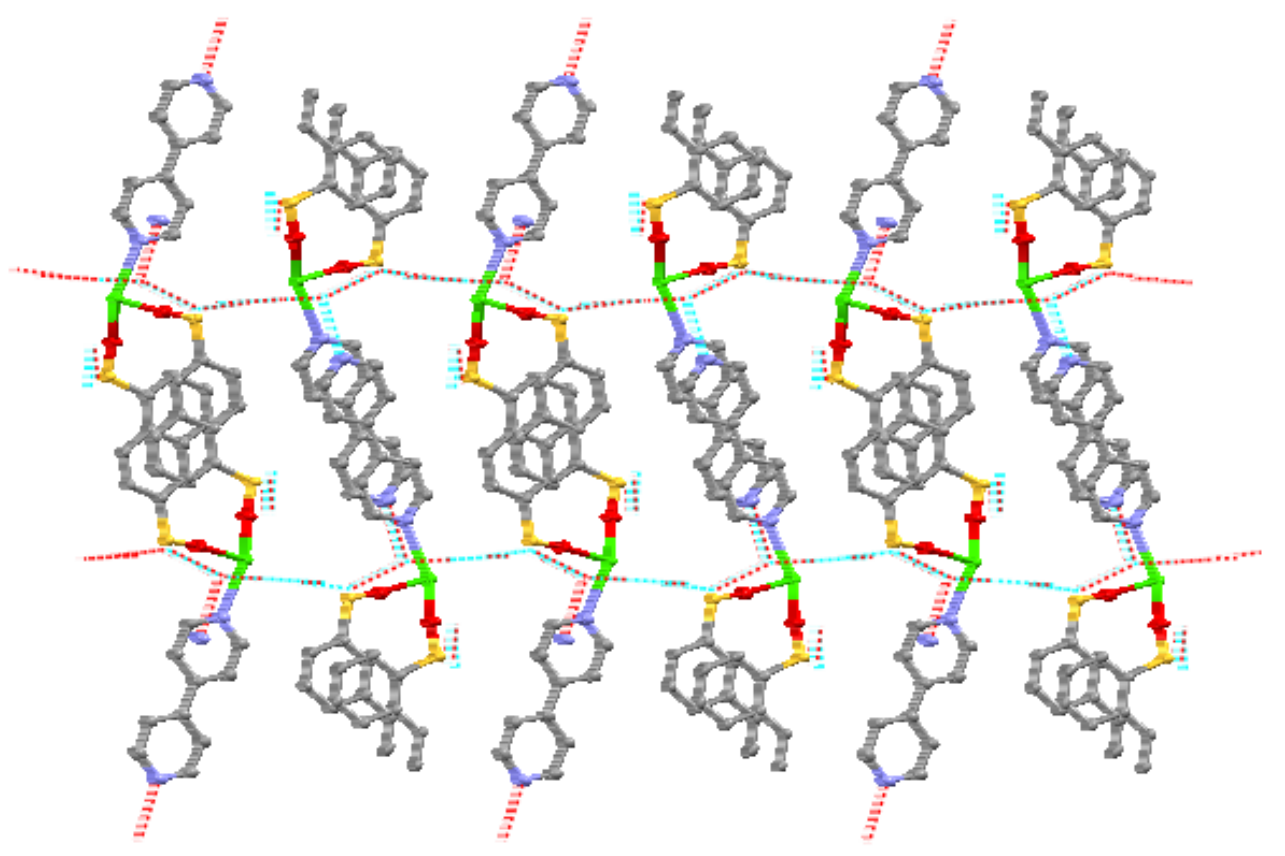

Table 1. Hydrogen-bond geometry $\left(\AA{ }^{\circ}{ }^{\circ}\right)$.

\begin{tabular}{ccccc}
\hline $\boldsymbol{D}-\mathbf{H} \cdots \boldsymbol{A}$ & $\boldsymbol{D}-\mathbf{H}$ & $\mathbf{H} \cdots \boldsymbol{A}$ & $\boldsymbol{D} \cdots \boldsymbol{A}$ & $\boldsymbol{D}-\mathbf{H} \cdots \boldsymbol{A}$ \\
\hline $\mathrm{O}(1 \mathrm{~W})-\mathrm{H}(1 \mathrm{~A}) \cdots \mathrm{O}(3 \mathrm{~W})^{\text {i }}$ & 0.85 & 2.14 & $2.961(2)$ & 163 \\
$\mathrm{O}(1 \mathrm{~W})-\mathrm{H}(1 \mathrm{~B}) \cdots \mathrm{O}(3)^{\text {ii }}$ & 0.84 & 2.02 & $2.803(2)$ & 155 \\
$\mathrm{O}(2 \mathrm{~W})-\mathrm{H}(2 \mathrm{~A}) \cdots \mathrm{O}(2)^{\mathrm{ii}}$ & 0.86 & 2.02 & $2.865(2)$ & 170 \\
$\mathrm{O}(2 \mathrm{~W})-\mathrm{H}(2 \mathrm{~B}) \cdots \mathrm{O}(3)^{\mathrm{iii}}$ & 0.85 & 1.95 & $2.798(19)$ & 172 \\
$\mathrm{O}(3 \mathrm{~W})-\mathrm{H}(3 \mathrm{~A}) \cdots \mathrm{N}(2)^{\text {iv }}$ & 0.86 & 1.90 & $2.755(2)$ & 172 \\
$\mathrm{O}(3 \mathrm{~W})-\mathrm{H}(3 \mathrm{~B}) \cdots \mathrm{O}(2)^{\mathrm{v}}$ & 0.84 & 2.19 & $2.963(2)$ & 154 \\
$\mathrm{O}(4 \mathrm{~W})-\mathrm{H}(4 \mathrm{~A}) \cdots \mathrm{O}(6)^{\mathrm{i}}$ & 0.84 & 2.08 & $2.878(19)$ & 157 \\
$\mathrm{O}(4 \mathrm{~W})-\mathrm{H}(4 \mathrm{~B}) \cdots \mathrm{O}(5)$ & 0.85 & 1.93 & $2.761(19)$ & 166 \\
\hline
\end{tabular}

Symmetry code: (i) $-1+x, y, z$; (ii) $1+x, y, z$; (iii) $2-x,-1 / 2+y, 1 / 2-z$; (iv) $1-x,-1 / 2+y, 1 / 2-z$; and (v) $1 / 2+x, 3 / 2-y, 1-z$.

\subsection{Thermogravimetric Analysis}

The thermogravimetric analysis of $\mathrm{Ca}$ (II) coordination polymer was performed under air atmosphere. The TG measurement confirms that $\mathrm{Ca}(\mathrm{II})$ coordination polymer is thermally stable up to $180{ }^{\circ} \mathrm{C}$. The TG curve indicates that $\mathrm{Ca}$ (II) coordination polymer starts to loose water molecules at $\mathrm{ca}$. $180{ }^{\circ} \mathrm{C}$ and completes dehydration at $c a .200{ }^{\circ} \mathrm{C}$. The mass loss is $12.36 \%$ in the range $180-200{ }^{\circ} \mathrm{C}$, which corresponds to the loss of four water molecules. On further heating, the TG curve shows a continuous mass loss up to $650{ }^{\circ} \mathrm{C}$ due to decomposition of $\mathrm{Ca}(\mathrm{II})$ coordination polymer. 


\subsection{Antitumor Activity}

The data of antitumor activities of $\mathrm{Ca}(\mathrm{II})$ coordination polymer and 1,6-naphthalenedisulfonic acid disodium salt are given in Table 2. Up to now, there have been no reports that calcium salts have antitumor activity. From Table 2, It can be seen that both $\mathrm{Ca}$ (II) coordination polymer and 1,6-naphthalenedisulfonic acid disodium salt exerted cytotoxic effect against human hepatoma SMMC-7721 cells, and the antitumor effect of 1,6-naphthalenedisulfonic acid disodium salt is better than that of $\mathrm{Ca}(\mathrm{II})$ coordination polymer. However, $\mathrm{Ca}(\mathrm{II})$ coordination polymer has stronger cytotoxicity against human lung adenocarcinoma $A 549$ cells with lower $\operatorname{IC}_{50}(27 \pm 1.2 \mu \mathrm{g} / \mathrm{mL})$ than that of 1,6-naphthalenedisulfonic acid sodium. The result of molar conductivity of the $\mathrm{Ca}$ (II) coordination polymer shows that the $\mathrm{Ca}$ (II) coordination polymer is a nonelectrolyte, so we think that the antitumor activity of $\mathrm{Ca}$ (II) coordination polymer is due to the joint action of the ligand and the $\mathrm{Ca}$ (II).

Table 2. Antitumor activities of $\mathrm{Ca}(\mathrm{II})$ coordination polymer and 1,6-naphthalenedisulfonic acid disodium salt.

\begin{tabular}{ccc}
\hline \multirow{2}{*}{ Compound } & \multicolumn{2}{c}{ IC $_{\mathbf{5 0}}(\boldsymbol{\mu g} / \mathbf{m L})$} \\
\cline { 2 - 3 } & SMMC-7721 & A549 \\
\hline 1,6-naphthalenedisulfonic acid sodium & $22 \pm 1.7$ & - \\
$\mathrm{Ca}(\mathrm{II})$ complex & $36 \pm 2.9$ & $27 \pm 1.2$ \\
\hline
\end{tabular}

- : no antitumor activity.

\section{Experimental Section}

\subsection{Materials and Methods}

The 1,6-naphthalenedisulfonic acid disodium salt, $\mathrm{Ca}\left(\mathrm{ClO}_{4}\right)_{2} \cdot 4 \mathrm{H}_{2} \mathrm{O}$ and 4,4'-bipyridyl ligands were purchased from Aldrich (St. Louis, MO, USA). All other regents used were analytical grade and used without further purification.

Elemental analysis $(\mathrm{C}, \mathrm{H}, \mathrm{N})$ was carried out on a Elementar Vario III EL elemental analyzer (Hanau, Germany). Infrared spectra were recorded as $\mathrm{KBr}$ discs using a Nicolet AVATAR 360 FTIR spectrophotometer in the range $4000 \mathrm{~cm}^{-1} \sim 400 \mathrm{~cm}^{-1}$. Thermogravimetric analysis was performed on a Shimadzu PT-40 with heating rate programmed at $5{ }^{\circ} \mathrm{C} \min ^{-1}$. X-ray diffraction data of the $\mathrm{Ca}(\mathrm{II})$ complex was collected on a Bruker smart CCD diffractometer.

\subsection{Synthesis of $\mathrm{Ca}(\mathrm{II})$ Coordination Polymer}

A $5 \mathrm{~mL}$ methanol solution of $0.5 \mathrm{mmol}(0.1555 \mathrm{~g}) \mathrm{Ca}\left(\mathrm{ClO}_{4}\right)_{2} \cdot 4 \mathrm{H}_{2} \mathrm{O}$ was added to a solution

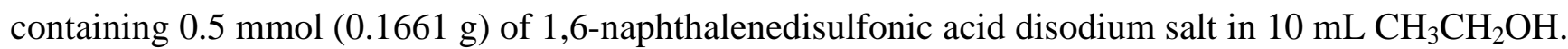
The mixture was stirred for $2 \mathrm{~h}$ at refluxing temperature. Then $0.5 \mathrm{mmol}(0.07809 \mathrm{~g}) 4,4^{\prime}$-bipyridyl was added to the above solution. The mixture was continuously stirred for $3 \mathrm{~h}$ at refluxing temperature. The white precipitates were collected by filtration. Then the white precipitates redissolved in $\mathrm{MeOH}$, and the single crystal suitable for X-ray determination was obtained from methanol solution after 20 days by evaporation in air at room temperature. Elementary analysis: calcd for $\mathrm{C}_{20} \mathrm{H}_{22} \mathrm{CaN}_{2} \mathrm{O}_{10} \mathrm{~S}_{2}$ : $\mathrm{C}$, 
43.27; H, 3.97; 5.05\%; found: C, 43.57; H, 3.58; and N, 4.73\%. IR $v_{\max }\left(\mathrm{cm}^{-1}\right): v\left(\mathrm{SO}_{3}{ }^{-}\right): 1301 \mathrm{~cm}^{-1}$, $1186 \mathrm{~cm}^{-1}, v(\mathrm{C}=\mathrm{N}): 1219 \mathrm{~cm}^{-1}, 800 \mathrm{~cm}^{-1}$ and $607 \mathrm{~cm}^{-1}, v(\mathrm{Ca}-\mathrm{N}): 519 \mathrm{~cm}^{-1}$ and $v(\mathrm{Ca}-\mathrm{O}): 417 \mathrm{~cm}^{-1}$.

\subsection{X-ray Crystallography}

Single crystal X-ray diffraction data were collected at 273(2) K on a Bruker smart CCD diffractometer using graphite-monochromatic Mo $K \alpha$ radiation $(\lambda=0.71073 \AA)$. The structure was solved by direct method and refined using a full-matrix least-squares technique against $F^{2}$ with anisotropic displacement parameters for non-hydrogen atoms with the program SHELXL-97 [17]. All hydrogen atoms were placed at calculated positions using suitable riding models with isotropic displacement parameters derived from their carrier atoms. Molecular graphics were drawn with the program package SHELXTL-97 crystallographic software package [18].

A summary of crystal data and relevant refinement parameters for $\mathrm{Ca}$ (II) coordination polymer are as following: formula, $\mathrm{C}_{20} \mathrm{H}_{22} \mathrm{CaN}_{2} \mathrm{O}_{10} \mathrm{~S}_{2}$; formula weight, 554.60; crystal system, orthorhombic; space group, $P 22_{1} 2_{1} 2_{1} ; a=6.7583(5) \AA ; b=14.8971(11) \AA ; c=22.8915(17) \AA ; \alpha=\beta=\gamma=90^{\circ} ; Z=4$; $F(000)=1152 ; \mathrm{T}=273(2) \mathrm{K} ; V=2304.7(3) \AA^{3}$; calculated density, $1.598 \mu \mathrm{g} \cdot \mathrm{m}^{-3}$; crystal size, $0.22 \mathrm{~mm} \times 0.20 \mathrm{~mm} \times 0.16 \mathrm{~mm} ; \mu=0.514 \mathrm{~mm}^{-1} ; S=1.022$; limiting indices, $-8 \leq h \leq 8,-18 \leq k \leq 15$, $-28 \leq l \leq 26$; reflections collected/unique, 13037 and $4511 ; R_{1}, w R_{2}$ [all data], 0.0235 and $0.0566 ; R_{1}$, $w R_{2}[I>2 \sigma(I)], 0.0221$ and $0.0557 ; R_{\text {int }}=0.0176$; goodness of fit on $F^{2}, 1.022$; largest diff. peak and hole, $0.173 \mathrm{e} \cdot \AA^{-3}$ and $-0.213 \mathrm{e} \cdot \AA^{-3}$. Selected bond lengths and angles are listed in Table 3.

Table 3. Selected bond lengths $(\AA)$ and angles $\left(^{\circ}\right)$ for $\mathrm{Ca}(\mathrm{II})$ coordination polymer.

\begin{tabular}{ccc}
\hline Bonds & Bond length $(\AA)$ & Angles $\left(^{\circ}\right)$ \\
\hline $\mathrm{Ca}(1)-\mathrm{O}(1)$ & $2.298(13)$ & - \\
$\mathrm{Ca}(1)-\mathrm{O}(4 \mathrm{~W})$ & $2.407(14)$ & - \\
$\mathrm{Ca}(1)-\mathrm{O}(4)$ & $2.426(13)$ & - \\
$\mathrm{Ca}(1)-\mathrm{N}(1)$ & $2.593(15)$ & - \\
$\mathrm{Ca}(1)-\mathrm{O}(2 \mathrm{~W})$ & $2.361(14)$ & - \\
$\mathrm{Ca}(1)-\mathrm{O}(1 \mathrm{~W})$ & $2.423(15)$ & - \\
$\mathrm{Ca}(1)-\mathrm{O}(3 \mathrm{~W})$ & $2.490(14)$ & - \\
$\mathrm{O}(1)-\mathrm{Ca}(1)-\mathrm{O}(2 \mathrm{~W})$ & - & $164.41(6)$ \\
$\mathrm{O}(2 \mathrm{~W})-\mathrm{Ca}(1)-\mathrm{O}(4 \mathrm{~W})$ & - & $92.61(6)$ \\
$\mathrm{O}(2 \mathrm{~W})-\mathrm{Ca}(1)-\mathrm{O}(1 \mathrm{~W})$ & - & $79.81(5)$ \\
$\mathrm{O}(1)-\mathrm{Ca}(1)-\mathrm{O}(4)$ & - & $98.95(5)$ \\
$\mathrm{O}(1)-\mathrm{Ca}(1)-\mathrm{O}(4 \mathrm{~W})$ & - & $86.44(6)$ \\
$\mathrm{O}(1)-\mathrm{Ca}(1)-\mathrm{O}(1 \mathrm{~W})$ & - & $85.04(6)$ \\
$\mathrm{O}(1 \mathrm{~W})-\mathrm{Ca}(1)-\mathrm{O}(4 \mathrm{~W})$ & - & $73.07(6)$ \\
$\mathrm{O}(2 \mathrm{~W})-\mathrm{Ca}(1)-\mathrm{O}(4)$ & - & $95.74(5)$ \\
$\mathrm{O}(4 \mathrm{~W})-\mathrm{Ca}(1)-\mathrm{O}(4)$ & - & $74.14(5)$ \\
$\mathrm{O}(1)-\mathrm{Ca}(1)-\mathrm{O}(3 \mathrm{~W})$ & - & $96.60(6)$ \\
$\mathrm{O}(4 \mathrm{~W})-\mathrm{Ca}(1)-\mathrm{O}(3 \mathrm{~W})$ & - & $142.14(5)$ \\
$\mathrm{O}(4)-\mathrm{Ca}(1)-\mathrm{O}(3 \mathrm{~W})$ & - & $68.10(4)$ \\
\hline & &
\end{tabular}


Table 3. Cont.

\begin{tabular}{ccc}
\hline Bonds & Bond length $(\stackrel{\AA}{\mathbf{A}})$ & Angles $\left(^{\circ}\right)$ \\
\hline $\mathrm{O}(2 \mathrm{~W})-\mathrm{Ca}(1)-\mathrm{N}(1)$ & - & $91.05(6)$ \\
$\mathrm{O}(1 \mathrm{~W})-\mathrm{Ca}(1)-\mathrm{N}(1)$ & - & $73.61(5)$ \\
$\mathrm{O}(3 \mathrm{~W})-\mathrm{Ca}(1)-\mathrm{N}(1)$ & - & $71.91(5)$ \\
$\mathrm{O}(1 \mathrm{~W})-\mathrm{Ca}(1)-\mathrm{O}(4)$ & - & $146.63(5)$ \\
$\mathrm{O}(2 \mathrm{~W})-\mathrm{Ca}(1)-\mathrm{O}(3 \mathrm{~W})$ & - & $93.68(5)$ \\
$\mathrm{O}(1 \mathrm{~W})-\mathrm{Ca}(1)-\mathrm{O}(3 \mathrm{~W})$ & - & $144.75(5)$ \\
$\mathrm{O}(1)-\mathrm{Ca}(1)-\mathrm{N}(1)$ & - & $81.10(5)$ \\
$\mathrm{O}(4 \mathrm{~W})-\mathrm{Ca}(1)-\mathrm{N}(1)$ & - & $145.23(5)$ \\
$\mathrm{O}(4)-\mathrm{Ca}(1)-\mathrm{N}(1)$ & - & $139.76(5)$ \\
\hline
\end{tabular}

\subsection{Antitumor Activity}

Human hepatoma SMMC-7721 cells and human lung adenocarcinoma $A 549$ cells were propagated continuously in culture and grown in RPMI 1640 medium with 10\% inactivated fetal calf serum and antibiotics. Cell harvested from exponential phase were seeded equivalently into 96 well plates and incubated for $24 \mathrm{~h}$, then the solid compounds studied were added in a concentration gradient. The final concentrations were maintained at $c /\left(\mu \mathrm{g} \mathrm{mL} \mathrm{m}^{-1}\right) 5,10,20,30,40,60$ respectively. The plates were maintained at $37{ }^{\circ} \mathrm{C}$ in a humidified $5 \% \mathrm{CO}_{2}-90 \% \mathrm{~N}_{2}-5 \% \mathrm{O}_{2}$ atmosphere and incubated for $48 \mathrm{~h}$, MTT solution was added, and the procedure described in [19] was then followed. The measurements of absorption of the solution concerned with the number of live cells were performed on spectrophotometer at $570 \mathrm{~nm}$.

\section{Conclusions}

In summary, we have synthesized a new one-dimensional helical chained $\mathrm{Ca}$ (II) coordination polymer, $\left[\mathrm{CaL}\left(4,4^{\prime} \text {-bipyridyl }\right)\left(\mathrm{H}_{2} \mathrm{O}\right)_{4}\right]_{n}$. The spectral properties, crystal structure and antitumor activity also have been investigated. Further investigation of the property and application of $\mathrm{Ca}(\mathrm{II})$ coordination polymer are currently in progress in our laboratory.

\section{Acknowledgments}

The authors would like to thank the National Natural Science Foundation of China (Nos. 21171132 and 20671073), the Promotive Research Fund for Excellent Young and Middle-aged Scientisits of Shandong Province (2010BSA07004) and Science Foundation of Weifang University.

\section{Appendix}

Crystallographic data for the structure reported in this paper has been deposited with the Cambridge Crystallographic Data Centre as supplementary publication No. CCDC 942222. Copy of the data can be obtained free of charge on application to CCDC, 12 Union Road, Cambridge CB2 1EZ, UK (Fax: +44-1223-336-033; E-Mail: deposit@ccdc.cam.ac.uk). 


\section{Conflicts of Interest}

The authors declare no conflict of interest.

\section{References}

1. Li, Z.H.; Xue, L.P.; Wang, L.; Zhang, S.T.; Zhao, B.T. Two-dimensional copper-based metal-organic framework as a robust heterogeneous catalyst for the $\mathrm{N}$-arylation of imidazole with arylboronic acids. Inorg. Chem. Commun. 2013, 27, 119-121.

2. Mu, Y.J.; Song, Y.J.; Wang, C.; Hou, H.W.; Fan, Y.T. Syntheses, structures and luminescence of a series of $\mathrm{Cd}(\mathrm{II})$-containing coordination polymers constructed from a long flexible bis-triazole ligand. Inorg. Chim. Acta 2011, 365, 167-176.

3. Rosi, N.L.; Eckert, J.; Eddaoudi, M.; Vodak, D.T.; Kim, J.; O’Keefe, M.; Yaghi, O.M. Hydrogen storage in microporous metal-organic frameworks. Science 2003, 300, 1127-1129.

4. Zhao, L.; Xu, G.F.; Tang, J. Carboxylato-bridged 3D polymeric networks of Pr(III): Synthesis, crystal structure, magnetic property and thermal behavior. J. Mol. Struct. 2010, 979, 160-164.

5. Della Rocca, J.; Lin, W.B. Nanoscale metal-organic frameworks: Magnetic resonance imaging contrast agents and beyond. Eur. J. Inorg. Chem. 2010, 2010, 3725-3734.

6. Saha, D.; Sen, R.; Maity, T.; Koner, S. Porous magnesium carboxylate framework: Synthesis, $\mathrm{X}$-ray crystal structure, gas adsorption property and heterogeneous catalytic aldol condensation reaction. Dalton Trans. 2012, 41, 7399-7408.

7. Tai, X.S.; Wei, N.; Wang, D.H. Synthesis, crystal structure and luminescent property of Mg (II) complex with $N$-benzenesulphonyl-L-leucine and 1,10-phenanthroline. Materials 2012, 5, $558-565$.

8. Tai, X.S.; Feng, Y.M.; Kong, F.Y.; Wang, D.Q.; Tan, M.Y. Synthesis, crystal structure and thermal stability of $1 \mathrm{D}$ chain coordination polymer $\left[\mathrm{Ca}(\mathrm{L})_{2}\left(\mathrm{CH}_{3} \mathrm{OH}\right)_{2}\right]$ n. China J. Inorg. Chem. 2008, 24, 831-834.

9. Tai, X.S.; Wang, D.F.; Zhao, Z.B. Synthesis, crystal structure and antibacterial activity of 2D hydrogen-bonds layered magnesium(II) complex. China J. Inorg. Chem. 2008, 26, 1490-1494.

10. Tai, X.S.; Du, L.C.; Zhao, Z.B. Synthesis, crystal structure and antibacterial activity of magnesium(II) complex with $N$-benzenesulphonyl-L-phenylalanine and 1,10-phenanthroline. China J. Inorg. Chem. 2011, 27, 575-579.

11. Tai, X.S.; Zhao, W.H.; Li, F.H. Synthesis, structural characterization and antitumor activity of a $\mathrm{Ca}$ (II)-schiff base complex. China J. Inorg. Chem. 2013, 29, 1328-1332.

12. Taylor-Pashow, K.M.L.; Della Rocca, J.; Huxford, J.; Lin, W.B. Hybrid nanomaterials for biomedical applications. Chem. Commun. 2010, 46, 5832-5849.

13. Geary, W.J. The use of conductivity measurements in organic solvents for the characterization of coordination compounds. Coord. Chem. Rev. 1971, 7, 81-122.

14. Nakamoto, K. Infrared and Ramen Spectra of Inorganic and Coordination Compounds, 3rd Ed.; John Wiley and Sons: New York, NY, USA, 1978; Volume 1, pp. 359-368.

15. Tai, X.S.; Li, F.H. Synthesis, crystal structure and antitumor activity of 1D coordination polymer of $\mathrm{Ca}(\mathrm{II})$ and $\mathrm{Na}$ (I) with N-p-tolysulfonyl-glycine. Asian J. Chem. 2013, 25, 4401-4403. 
16. Tai, X.S.; Wang, D.H.; Zhao, W.H. Synthesis, crystal structure and antibacterial activity of calcium(II) complex of 2-formyl-benzenesulfonato-hydrazine. Asian J. Chem. 2013, 25, 4427-4430.

17. Sheldrick, G.M. SHELXL-97, Program for Crystal Structure Solution; University of Göttingen: Göttingen, Germany, 1997.

18. Sheldrick, G.M. SHELXTL-97, Program for Crystal Structure Refinement; University of Göttingen: Göttingen, Germany, 1997.

19. Dodoff, N.; Grancharow, K.; Gugova, R.; Spassovska, N. Platinum(II) complexes of benzoic-and 3-methoxybenzoic acid hydrazides. Synthesis, characterization, and cytotoxic effect. J. Inorg. Biochem. 1994, 54, 221-233.

(C) 2013 by the authors; licensee MDPI, Basel, Switzerland. This article is an open access article distributed under the terms and conditions of the Creative Commons Attribution license (http://creativecommons.org/licenses/by/3.0/). 